\title{
Building Strategic Competitiveness of UMKM in South Sulawesi Through Strategic Leadership, Innovation Process, Entrepreneurial Orientation and Business Performance (Typology Miles \& Snow and Quantitative Model Typology Analysis)
}

\author{
Abdul Rahman Kadir \\ Department of Management Faculty of Economics and Business Hasanuddin University \\ Najmi Kamariah \\ Business Administration Study Program STIA LAN Makassar
}

\author{
St. Rukayah \\ Faculty of Economics Fajar University \\ Syarifuddin Sulaiman
}

Ph.D. scholar, Post Graduate School of Economics Hasanuddin University

\begin{abstract}
This study aims to formulate the strategic competitiveness of UMKM by prioritizing the opportunities and resources that have to fix all activities of UMKM by formulating and setting long-term goals. This study also aims to test how much influence the strategic leadership, innovation process, and entrepreneurial orientation to business performance. The research was conducted in Makassar, Maros, Palopo Pare-Pare, Bone, Wajo and Gowa which had more UMKM compared to other areas in South Sulawesi with 189 samples. This type of research problem directs the strategic decision to UMKM. The managerial strategic decision of this research is within the range of Miles \& Snow's typology analysis. This research also uses Structural Equation Model analysis technique to test the variable that can support the strategic competitiveness of UMKM. The findings of this study indicate that the appropriate strategy for South Sulawesi UMKM is prospectors strategy. The result of the statistical analysis shows that innovation variable has no significant effect to the performance of UMKM business. The limitation of this research is the absence of specific strategic decisions in the field of UMKM business, so it can be a reference for researchers in the future.
\end{abstract}

Keywords: strategic competitiveness, strategic leadership, innovation processes, and entrepreneurial orientation

\section{Introduction}

UMKM sector is a sector that needs to get serious attention from the government and society because it is very real that UMKM (micro and small enterprises) is one contributor to employment opportunities, the growth of gross domestic product (GDP), and non-oil exports. This type of business is able to cope with the storm of crisis and also has the ability to recover faster than the larger business units. UMKM have an important and strategic role in the national economic development. In addition, to play a role in economic growth and employment, UMKM also plays a role in distributing the results of development. So far, UMKM has contributed 57,60\% Gross Domestic Product (PBD) and employment rate about 97\% of all national workforce (UMKM Business Profile by LPPI and BI 2015). Not much different from the record of Kadin (Indonesian Chamber of Commerce), the contribution of 
the UMKM sector to gross domestic product increased $57.84 \%$ to $60.34 \%$ in the last five years. Labor absorption in this sector also increased from $96.99 \%$ to $97.22 \%$ in the same period.

UMKM has also been proven not affected by the crisis. When the crisis hit the period of 1997-1998, only UMKM were able to remain strong. Data from the Central Bureau of Statistics show that after the economic crisis of 1997-1998, the number of UMKM has not decreased, it has increased, even absorbing 85 million to 107 million workers until 2012. In that year, the number of entrepreneurs in Indonesia is 56,539,560 units. Of this amount, Micro Small and Medium Enterprises (UMKM) of 56,534,592 units or 99.99\%. The rest, about $0.01 \%$ or 4,968 units is a major undertaking. During 2011 to 2012 there was growth in UMKM as well as a decline in big business. If in 2011, large businesses reached $41.95 \%$ the following year only $40.92 \%$, down about $1.03 \%$. In the UMKM going the opposite. If the medium enterprises in 2011 only 13.46\%, in 2012 reached $13.59 \%$. There was an increase of $0.13 \%$. In contrast to small businesses, there was a slight decrease from 2011. In that year reached $9.94 \%$ but in 2012 only reached $9.68 \%$, it means decreased by about $0.26 \%$. A significant increase occurred in micro business, if the year 2011 only reached $34.64 \%$, in 2012 managed to reach $38.81 \%$ an increase of $4.17 \%$.

These conditions and facts are in line with empirical research conducted by Demirbag et al. (2006) concluded that the success of small- and medium-scale enterprises has a direct impact on economic development in both developed and developing countries. The existence of UMKM today is very important because of the main characteristics it has, one of them because it is a labor-intensive business that absorbs a lot of labor (Tambunan, 2012). UMKM have the ability to create employment at minimum cost, they are pioneers in the world of innovation and have the high flexibility that enables such businesses to meet customer needs (Brock and Evans, 1986).

Although quantitatively, small businesses are dominant Indonesian economic actors, in reality, the sector is in a marginal position. Small businesses face competition situations with medium and large enterprises both in the input and output markets. Micro and Small Enterprise Development is an integrated part of Small and Medium Enterprises (UMKM) development program in South Sulawesi. Its development activities are aimed at being one of the pillars of the populist economy that can be a major driver of the regional economy, more particularly for the realization of the "Gerbang Mas Taskin and Agribusiness Commodities" program in South Sulawesi. The attention of the South Sulawesi Provincial Government to this sector is very large. This is evidenced by the existence of strategies, programs and action plans to build Micro and Small Enterprises (MSEs). Several programs have been implemented such as training and mentoring programs, access to capital, and market access assistance for the business. However, the facts on the ground indicate that not all programs are running effectively, which may impact the potential decrease in the performance of Micro and Small Enterprises in South Sulawesi (Dinas Koperasi dan UKM Sulawesi Selatan, 2012).

Various empirical studies indicate that the small business sector manufacturing sector that experienced growth only business that produces certain superior products. Therefore, efforts to identify investment opportunities in small business activities that produce superior products that have the power to develop a need to be done. In addition to having a high enough added value also absorb a lot of workforces. Although small businesses contribute significantly to the Indonesian economy, like other small businesses in the world are hindered by various obstacles such as lack of innovation, lack of initiative and capability for new technologies, thus becoming a substantial cause that hampers the growth performance of small businesses (Kuswantoro, 2012).

Organizational performance or often referred to as corporate performance is an indicator of success rate in achieving company goals. Good business performance 
demonstrates the success and efficiency of corporate behavior. Many studies use different indicators to measure organizational performance. Agarwal et al., (2003) which measures organizational performance using two-dimensional constructs. The first dimension is objective performance, which includes financial performance or performance based on marketing such as usage level, profitability, and market share. While the second construct dimension is subjective performance. Subjective performance is a performance measurement based on measurement of customers and employees, such as service quality, customer satisfaction, and employee job satisfaction.

Miles et al. (1998) suggest that measuring organizational performance in small and medium-sized enterprises is better suited to using the growth approach because small firms are generally less open in their financial statements making it difficult to interpret. Cole and Cooper (2005) argue that consensus on appropriate performance measurements does not exist, and generally previous researchers have focused on variables where the information is readily available, Beal (2000) and Covin and Slevin (1989) further stated that to anticipate not the availability of objective business performance data in a study, it is possible to use subjective measures of performance, based on manager or owner perceptions.

The emergence of problems in small business is caused by several factors. Factors that influence human resources include the level of education and skills of entrepreneurs, especially those related to marketing. Entrepreneurs with adequate skills will be able to develop marketing plans and strategies, including product development, pricing policies, promotion, and distribution. (Tambunan 2003); one of the causes of Indonesia's small business performance is much lower than that of small enterprises in developed countries such as Europe, USA, Taiwan and South Korea due to the low degree of development or information technology. Whereas in the era of free trade and globalization of the world economy, technology and human resources are two dominant factors in determining the level of competitive advantage of a product or company. In general, entrepreneurs or small business owners/managers are less able to read the environment, because of the lack of accessible information about potential market opportunities and bright prospects (Hassim et al., 2011). As a result, product marketing tends to be static and monotonous, both in terms of product diversification, quality, and market.

Small businesses have specific characteristics, as proposed by Mintzberg (1992), that the small business sector as an organization that has an entrepreneur organization with characteristics such as organizational structure is very simple, has a unique character, without elaboration, without excessive staff, slack work, a small management hierarchy, few formalized activities, very few using the planning process, rarely providing training for employees, employers are often difficult to distinguish between personal assets and corporate assets, poor accounting systems and often do not have them, and entrepreneurs have a nature in the face of investment almost the same as individuals. According to Pattimukay (2008), said that to build the soul of entrepreneurial leadership is an act of change that leads to increased creativity, innovation, intuition, and leadership skills, motivation, and courage to take risks in the organization. A leader must be able to influence the behavior of subordinates to cooperate and work productively to achieve organizational goals (Hasibuan, 2006).

In the face of challenges managers or important owners/managers increase their capability in deciding the direction of adaptive and innovative business development to survive in turbulent conditions (Gibson et al., 2006). Companies or organizations need to have the strategic flexibility to respond to problems quickly. One of the fundamental efforts is to make proper internal and healthy corrections, the organization is professionally managed by conducting service innovations so as to become a high-mobility developing company, in line with the demands of environmental development (Amos, 2007). This study aims to formulate the strategic competitiveness of UMKM by prioritizing the opportunities and 
resources that have to fix all activities of UMKM by formulating and setting long-term goals. This study also aims to test how much influence the strategic leadership, innovation process, and entrepreneurial orientation to business performance.

\section{Literature Review}

\section{Typology Miles \& Snow}

Strategies can be identified on the basis of most elements of the organization's orientation to market product development, Miles and Snow (1978) state that there are four types of strategies, namely Prospectors, Defenders, Analyzers, and Reactors. "The focus is primarily on strategy and its correlation, not the process used to formulate and implement the strategy" (Snow and Hambrick, 1980), the strategy typology based on that definition is categorized into a contented strategy. Another strategy typology is a strategy based on process or strategy based on making. This concept is proposed by Mintzberg (1973).

Focusing on the motive for making decisions who will make alternatives to how strategies are evaluated, the scope of linkage decisions, organizational goals of the flexibility of the age model of the organization, and the type of resources for modeling strategies. This concept is called the strategy of making (making strategy). Based on the focus of the study, Mintbezberg (1973) suggested three forms of strategy-making: Entrepreneurial, Adaptive and Planning. The making of a strategy can be defined: "an organization-level process that encompasses the range of activities in terms of strategic missions and goals. These activities include analyzing, planning, decision making, strategic management, and shared aspects of the organization's culture, shared value systems and corporate vision (Hart, 1992).

The company's strategic activities include analysis, planning, decision making, strategic management, and many aspects of the organization's culture and vision. Miles and Snow have different approaches to Mintzberg, which applies the strategy typology to the process or strategy making of these two typologies with regard to business-level strategies that are related to organizational performance, in other words, both of these typologies must have a relationship. A recent survey of empirical studies (Segev 1987) links business-level strategies, based on several relationships between strategy, strategy-making, and organizational performance. In his analysis, Segev (1987) made a reciprocal link between two typologies, the four types of strategies from Miles \& Snow, with possible combinations with the three forms of strategy from Mintzberg, and several combinations to produce high performance.

Miles and Snow (Segev, 1987), there are four types of strategies: a) Prospector is The type of company that uses a strategy that is concerned with innovation, and creativity to create new products or new markets. The company strives to always be a pioneer in competing, and willingly sacrifices internal efficiency to innovate, and create; b) Defenders are Organizations that emphasize the use of stability strategies and business viability. The company maintains its core business or core business, without much change; c) Analyzer is: Companies that use strategies between defenders and prospectors. This means that the company is not too brave to take big risks in innovating, but still trying to create excellence in its service to the market, and d) Reactors are Types of firms that are more pressed by the environment because they pay less attention to environmental changes and competition systems. Companies of this type are more concerned with efficiency, reduce costs including pressing on human resources.

\section{Strategic Leadership and business performance}

Strategic leadership is one's ability to anticipate, dream, maintain flexibility, think strategically, and work with others to initiate change that will create a better future for the organization (Daff, 2005). While Hitt et al. (1999) argues that effective strategic leaders among others have the skills to (1) anticipate and forecast events within an organization's 
external environment that have the potential to affect organizational performance; (2) seek and maintain competitive advantage by building core competencies and choosing the right markets (4) building highly effective, efficient and motivated employee teams, (5) determining the right goals and priorities to achieve them, and (6) establishing a highly effective, efficient and motivated team of employees; to be an effective communicator.

The style of a leader influences the existing climate within the organization (Komariah 2012). According to Cannon \& Edmondson (2001) explains that there are three impacts generated by organizational climate namely impact on employee motivation, employee development and retention, and employee performance. The results of all of them have an impact on business performance. This result is similar to that of Yang (2006), entitled The Effects of Leadership and Entrepreneurial Orientation of Small and Medium Enterprises on Business Performance in Taiwan. Thus, the following hypothesis is proposed:

\section{H1: Strategic Leadership directly influence business performance}

\section{Innovation and business performance}

Innovation is the ability to assess relationships, opportunities and then take advantage of them. The essence of innovation activities is how to conduct activities that add value and excellence from current conditions (Dhewanto et al., 2015). Innovation needs to be accompanied by the formulation of strategies to determine the form of economically, technically and technically feasible innovation. Strategies relate to effectiveness rather than efficiency and are a process of analyzing the environment as well as designing conformity between organizations, resources, goals, and environments (Proctor, 2000). In solving the constraints and implementation of UMKM innovation it is assumed that the factors that become the focus of development are human resources or entrepreneurs themselves. Research conducted by Ardiana et al. (2010) explains that the quality of human resources in UMKM will affect the performance of UMKM. Kisengi, (2014) also explained that there is a relationship between education and entrepreneurial behavior.

Innovation is a driver of corporate growth, driving future success and driving the company to survive in the global economy. This shows that innovation is important for any commercial company in the world (Hassim et al, 2011). Innovation is also the answer to the dynamic conditions, namely the rapidly changing business environment (Awang et al, 2012). According to Gray, et al. (2002) that the innovation capability of a company will ensure the company's competitive ability. Therefore innovation is an important concept to be studied because innovation also gives a big impact to the success of the company. In the opinion of Cooper (1995), innovation plays an important role in the organization because innovation creates and maintains sustainable competitive advantage.

Creativity and innovation by definition involve the creation of something new that is the center of the entrepreneurial process (Barringer and Ireland, 2006). Creativity and innovation are considered inseparable from entrepreneurship, which in turn is embodied in the act of starting and running a company (Baldacchino, 2009). Creativity is not enough just to come up with ideas. Although quantitatively, small businesses are dominant Indonesian economic actors, in reality, the sector is in a marginal position. Small businesses face competition situations with medium and large enterprises both in the input and output markets. Thus, the following hypothesis is proposed:

\section{H2: Innovation directly influence business performance}

\section{Entrepreneurial orientation and business performance}

Several studies have shown a significant positive relationship between entrepreneur orientation and firm performance both in large companies and UMKM such as Covin and Slevin (2006); Wiklund (1999); Lee and Tsang (2001); The orientation of entrepreneurs that 
reflects the company's tendency to be innovative, seeking opportunities, risk-taking, autonomous and aggressive competitively affects organizational performance, has also been demonstrated by Dess, Lumpkin \& Covin (1997). Research on the interaction between strategic and environmental orientation has been largely undertaken by previous researchers (Covin and Covin 1990; Lee and Miller, 1996). In general, the study states that the suitability of the relationship between strategy and environment affects organizational performance. As a result, product marketing tends to be static and monotonous, both in terms of product diversification, quality, and market. This happens because the knowledge and skills of employers or owners/managers of small businesses are still weak plus access to less market information and support institutions that have not played a role particularly in terms of helping marketing.

Hurley et al's (2003) finding that entrepreneurial orientation is one of the factors of innovation success. The effect of total innovation ability variables can strengthen the influence between entrepreneurship orientation on business performance and the ability to innovate strengthen the influence of entrepreneurship orientation on business performance. Awang, et al (2009); Hassim et al (2011); and Hafeez et al (2012). The ability to innovate can improve between entrepreneurship orientation to business performance and the ability to innovate can create a business performance. Some studies have considerable attention to issues of innovation ability, entrepreneurship orientation, market orientation and learning orientation on performance. Findings Zhou et al. (2005) in his research stated that entrepreneurship orientation has a positive effect on product performance, because it is believed that entrepreneurial orientation plays a role that seats in ensuring the success of a business program is run and provide support and encouragement through entrepreneurial attitudes to achieve success in the business (Hunter and Rogres, 1993, 153).

Entrepreneurial behavior combined with market-oriented capabilities is a potential source of competitive advantage and the key to UMKM (Hafeez et al 2012). Furthermore, Lumpkins \& Dess (1996) stated that entrepreneurship orientation is a decision on the processes and methods of informing the entrepreneurial activities of the company. Entrepreneurship deals with the orientation of corporate strategies such as styles, methods and decision-making practices (Lumpkins \& Dess, 1996). As the study findings, Chow (2006) states that the entrepreneurship orientation has an influence on performance at large companies. Krauss (2005) also found in his study findings that entrepreneurship orientation is a description for companies to engage in innovative attitudes, seek opportunities, dare to take risks and competitive on performance.

Hafeez et al (2012) in his findings that the entrepreneurial orientation has a causal relationship with the performance of Small and Medium Enterprises (UMKM). In addition, Baum et al (2001) research, stated that entrepreneurship has a direct influence on business performance in entrepreneurial elements such as internal locus, need for achievement, extroversion, education experience, and self-reliance affect business growth. Therefore a UKK manager should be more proactive in finding new opportunities and incorporating risk-taking elements into the company's strategy in order to improve business performance. Furthermore, the findings of Zhou et al. (2005) in his research stated that entrepreneurship orientation has a positive influence on product performance, because it is believed that entrepreneurial orientation plays a role that seats in ensuring the success of a business program that runs and provides support and encouragement through entrepreneurial attitudes to achieve success in the business (Hunter and Rogres, 1993).

The findings Ferreria \& Azevedo (2008), suggests that the entrepreneurial orientation is one of the resources and capabilities of the company. Further according to Dess et al. (1997) states that entrepreneurship orientation is the attitude of looking for opportunities, dare to take risks and decision-making that is driven by the nature of leadership that is strong and have a certain value. Meanwhile, according to Miller and Frisen (1984) suggests that 
companies have more entrepreneurship orientation make market innovations, dare to run a risky business and start proactive innovations. Entrepreneurship activities are usually associated with the activity of producing a new or different product or service, more specifically, by utilizing resources and expanding its market (Drucker, 1993).

Research conducted by Lee and Tsang (2001) suggests that the orientation of entrepreneurship affect the company's performance. The orientation of entrepreneurship which is shown with the attitude of the need for achievement, the locus of control, selfreliance and extroversion from the owners of UMKM is high enough factor that can improve the performance of their business, Need achievement in the team will give idea or vision and implement the idea until to fruition. While the locus of control is a belief that success is due to the efforts of self. Where the orientation of entrepreneurship consists of elements (1) need for achievement (2) internal locus of control (3) self-reliance (confidence) and (4) extroversion (openness).

The findings of Hassim et al (2011) suggest that there is a significant relationship between entrepreneurship orientation and performance. Awang, et al (2009), suggests that autonomy and innovation are significantly and positively related to performance. The moderating effects indicate a significant interaction effect between human resources and information technology related proactively to performance. This strongly supports a resourcebased view, when the effects of entrepreneurial orientation and moderation of environmental influences indicate significant changes in relationships. Hassim et al (2011), suggests an important reason for UMKM managers/owners in formulating and implementing strategies to improve business performance, UMKM also need to improve their products and services because companies that innovate will succeed in growing and survival opportunities. UMKM enterprise management must also ensure that all elements of entrepreneurship orientation such as innovation, proactiveness, and risk-taking must be practiced within the organization. Thus, the following hypothesis is proposed:

\section{H3: Entrepreneurial orientation influence business performance}

Based on the description of the literature review explaining the relationship between strategic leadership, innovation, entrepreneurial orientation to business performance.

\section{Figure 1. Conceptual Framework}

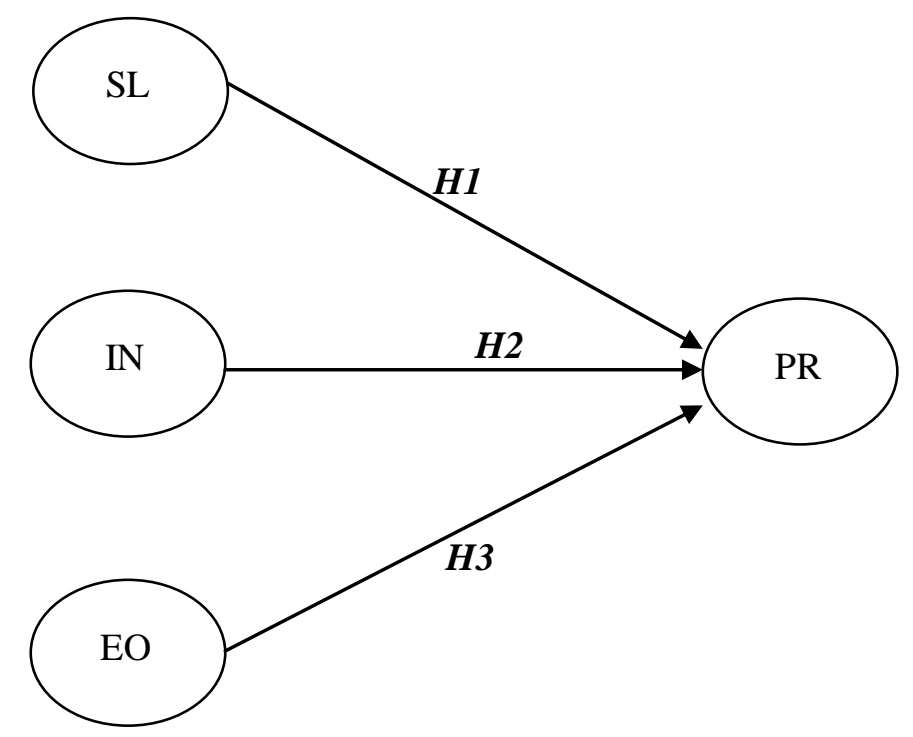

Note: SL: strategic leadership; IN: Innovation; EO: Entrepreneurial Orientation; dan PR: Performance 


\section{Research design}

This study aims to formulate the strategic competitiveness of UMKM by prioritizing the opportunities and resources owned to fix all activities of UMKM by formulating and setting long-term goals. This type of research problem directs the strategic decisions of UMKM. The managerial strategic decisions of this research are within the scope of the Miles \& Snow typology analysis. Miles \& Snow typology strategy as an effort of UMKM to fix all of its business activities by formulating and defining the mission and purpose of UMKM through stages of analysis, planning, decision making, strategic management, and many aspects of organization and vision.

This study also aims to test how much influence the strategic leadership, innovation process, and entrepreneurial orientation on business performance with quantitative methods using statistical tests. In this study, data were collected through explanatory survey method with the variables studied, namely strategic leadership, innovation, entrepreneurial orientation, and performance. This data consists of primary and secondary data. Primary data obtained from a set of questionnaires as a measuring tool, while secondary data taken from the literature and documents or reports related to the object of research. Sampling using proportional sampling and quota sampling with criteria that is the owner of the business, willing to fill out the questionnaire.

The population of this study were all UMKM in South Sulawesi, the sample of this study was UMKM in food, chemical \& construction, metals \& electronics, and handicrafts business in Makassar, Maros, Palopo Pare-Pare, Bone, Wajo and Gowa UMKM more than other areas in South Sulawesi. A total of 500 questionnaires were distributed, but as many as 189 returned questioners. This research uses Structural Equation Model analysis technique.

\section{Discussion}

\section{Internal and External Environment Analysis}

The low performance of small businesses is caused by many factors. In reality, small businesses still lack competitiveness, lack of innovation, and market access. In addition, several research results mentioned that the factors causing the failure of small and medium enterprises to grow are: (1) management incompetence, (2) poor decision-making ability, (3) lack of experience, (4) weak financial control (Idrus, 1999). The relationship between entrepreneurship and company performance has been assessed over time, some argue that it is difficult for people to act entrepreneurially in the bureaucracy. So far, the performance measurement in a business is only based on the financial aspect. Measuring the performance of the financial aspects is important but there are other aspects that are also important and need to be considered such as customer aspects, internal business processes and learning and growth process.

So the emergence of problems in small business is caused by several factors. Factors that influence human resources include the level of education and skills of entrepreneurs, especially those related to marketing. Entrepreneurs with adequate skills will be able to develop marketing plans and strategies, including product development, pricing policies, promotion, and distribution. (Tambunan 2003); one of the causes of Indonesia's small business performance is much lower than that of small enterprises in developed countries such as Europe, USA, Taiwan and South Korea due to the low degree of development or information technology. Whereas in the era of free trade and globalization of the world economy, technology and human resources are two dominant factors in determining the level of competitive advantage of a product or company.

In general, entrepreneurs or small business owners/managers are less able to read the environment, because of the lack of accessible information about potential market opportunities and bright prospects (Hassim et al., 2011). So far, there has not been sufficient 
studies on the success of small businesses that have potential demands, so it is necessary to find and recognize that the key factor is in the hands of employers or owners/managers and therefore absolute innovative behavior. Small businesses have specific characteristics, as proposed by Mintzberg (1992), that the small business sector as an organization that has an entrepreneur organization with characteristics such as organizational structure is very simple, has a unique character, without elaboration, without excessive staff, slack work, a small management hierarchy, few formalized activities, very few using the planning process, rarely providing training for employees, employers are often difficult to distinguish between personal assets and corporate assets, poor accounting systems and often do not have them, and entrepreneurs have a nature in the face of investment almost the same as individuals.

The negative impact of this change is most felt by national economic actors belonging to small (industry) companies. This is because the local market will be filled with more qualified and competitive foreign products in the field of prices. On the other hand, the existence of small businesses is generally still vulnerable in the face of global competition (Idrus, 1990). Small businesses are almost always less competitive with both types of markets because the ability to create added value and efficiency levels in production activities is still very low. The data mentioned previously have proved so big role of UMKM to the Indonesian economy, even though UMKM business does not always run smoothly, there are still many obstacles and constraints, both internal and external to be faced by the perpetrators of UMKM.

\section{Figure 2. Internal and External Factors}
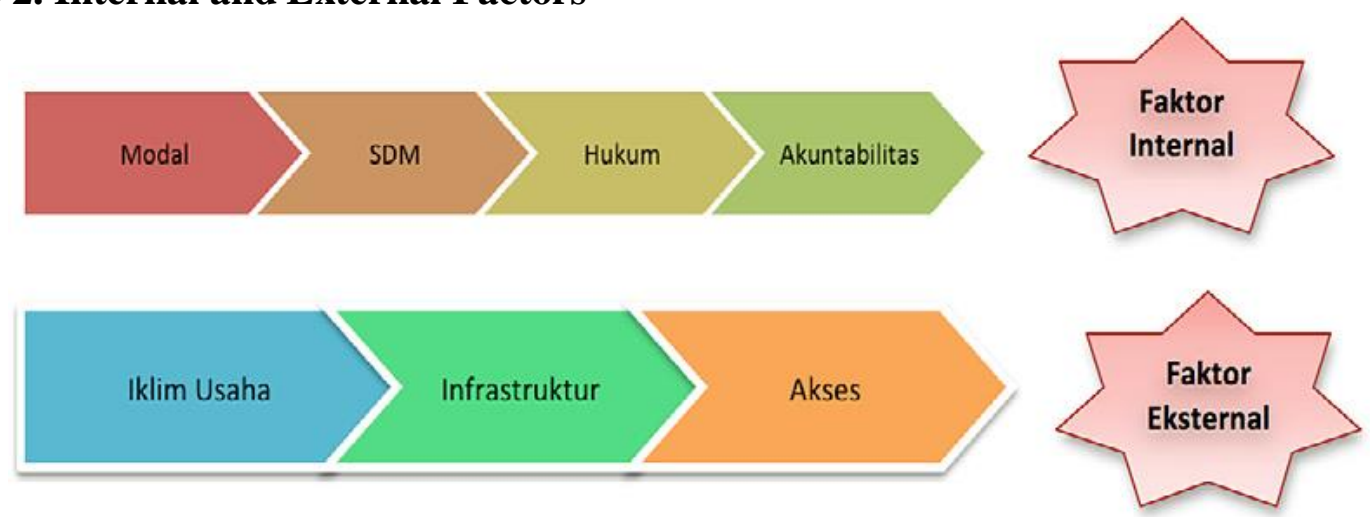

Various studies have found that one of the serious constraints faced by small businesses in the field of production is the low quality of human resources. The educational background of entrepreneurs, in general, is still low, making it difficult to understand or master the necessary technology and difficult to accept/adapt to the process of renewal due to the rapid development of science and technology. Only a small proportion have ever participated in technical and management training, whereas the sustainability of factory activities, such as for making automotive components, requires training which is a must for the company (Bambang, 2006). These results are supported also by data from Human Development Report (2006) issued by UNDP, Indonesia's position in terms of human resource quality (human development index) is ranked 108th out of 177 countries. Compared with several neighboring countries, namely Singapore (25), Brunei Darussalam (34), Malaysia (61), Thailand (74), Philippines (84), Vietnam (109), Cambodia (129), Myanmar (130), Laos ( 133), and Timor Leste (142). The data shows that Indonesia's competitiveness has not met expectations.

In the context of increasing competitiveness, knowledge acquisition is an important factor to boost competitiveness. This is where the biggest weakness of Small Business. In addition to the less-qualified tbsp factors that often occur in Small Business is the capital and marketing that affect the business performance of Small Business. Micro and Small 
Enterprise Development is an integrated part of Small and Medium Enterprises (SME) development program in South Sulawesi. Its development activities are intended as one of the pillars of the populist economy that can become the main driver of the regional economy. Small businesses still lack competitiveness, lack of innovation, and market access. In addition, several research results mentioned that the factors causing the failure of small and medium enterprises to grow are: (1) management incompetence, (2) poor decision-making ability, (3) lack of experience, (4) poor financial control (Scarborough and Zimmerer, 1993, Idrus, 1990).

\section{Typology Miles \& Snow Analysis}

Based on the results of internal and external environmental analysis shows SMEs should implement prospectors strategy. SMEs should prioritize innovation, and creativity to create new products or new markets. SMEs strive to always want to be a pioneer in competing, and willing to sacrifice internal efficiency to innovate and be creative. This strategy needs support from all stakeholders and has the ability so that MSME resource management emphasizes change and high creativity. If internal resources do not meet, MSMEs will be willing to seek from external sources even at high cost. MSMEs with prospector strategy usually face greater environmental uncertainty than MSMEs that have strategies other than prospectors, so that the need for greater information on MSME prospector in order to improve business performance.

\section{Structural Equation Model}

\section{Table I.}

Correlation between independent and dependent variable

\begin{tabular}{lllrrrr}
\hline Variables & & Variables & Estimate & \multicolumn{1}{c}{ S.E } & \multicolumn{1}{c}{ C.R } & P-value \\
\hline SL & $\rightarrow$ & PR & $0.434^{*}$ & 0.173 & $2.516^{*}$ & 0.012 \\
IN & $\rightarrow$ & PR & 0.074 & 0.051 & 1.462 & 0.144 \\
EO & $\rightarrow$ & PR & $0.202^{*}$ & 0.092 & $2.192^{*}$ & 0.028 \\
\hline
\end{tabular}

Note: * The correlation is significant at 0,05 level

The next step in the results of this study is to measure how big the correlation between independent variables SL, IN, and EO and the dependent variable PR by doing path analysis. The results in Table I show that SL is shown to affect PR (0.434), indicating that H1 is acceptable. EO proved to affect PR (0.202), indicating that $\mathrm{H} 3$ is accepted. IN is not proven to affect PR (0.074), indicating that $\mathrm{H} 2$ is rejected, the results of the complete analysis are presented in Figure 3.

\section{Figure 3.}

Correlation between independent and dependent variable 


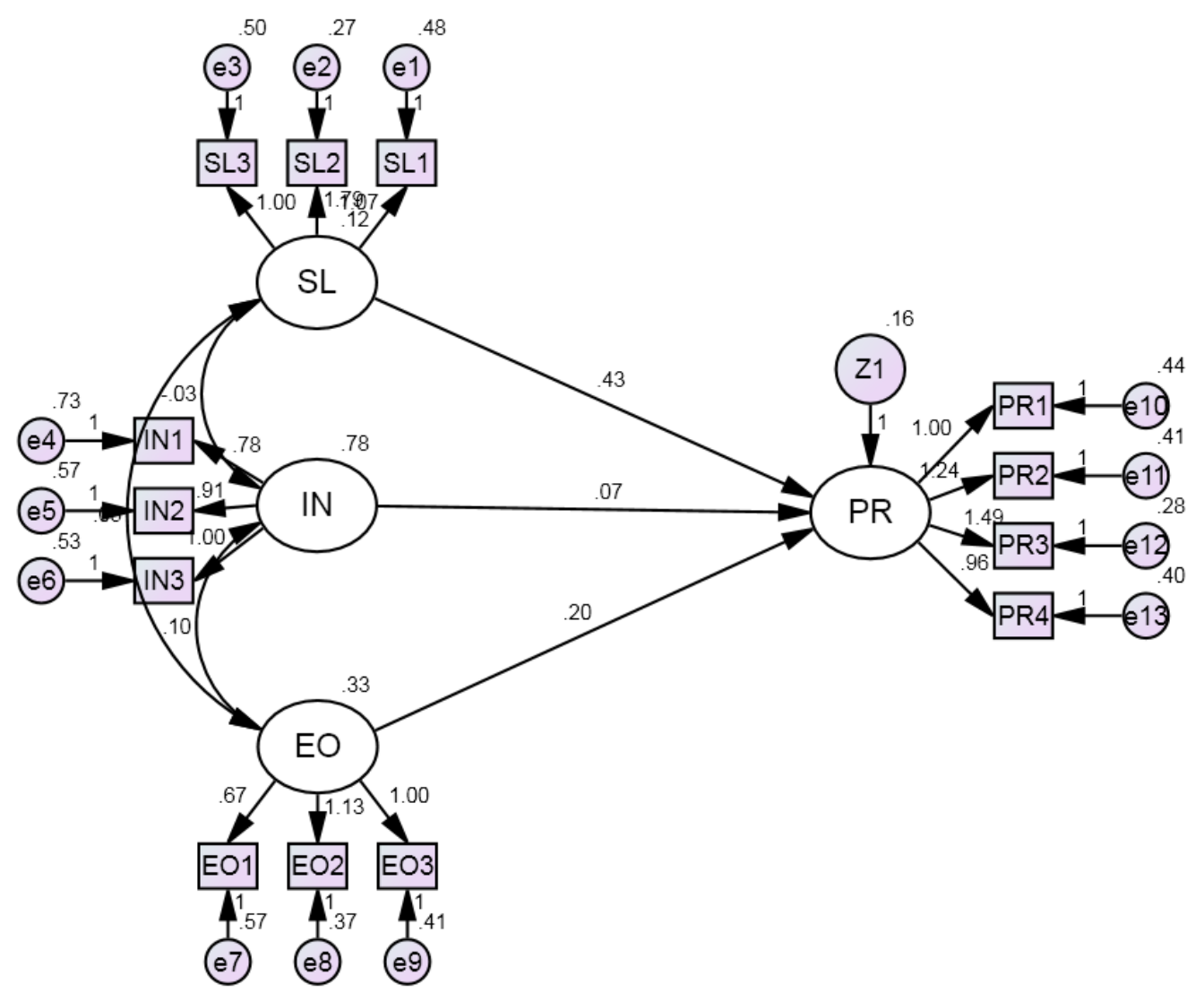

The findings of this study indicate that innovation has no significant effect on business performance. The constraints faced by small businesses are related to innovation is one of the basic instruments of new growth strategies to enter the market, to increase existing market share and provide companies to be competitive. (Günday et al., 2011). One way to develop and improve competitive advantage and improve performance is through the utilization of resources and improving innovation for small businesses (Hilmi and Ramayah, 2008). A company that is able to innovate will enable it to survive in competition and gain significant benefits. A review of the management literature on innovation relationships with company performance shows inconsistent results. A number of researchers found innovation to have a positive relationship with company performance (Garcia \& Calantone, 2002). Lin and Chen (2007) suggest that innovation is an important factor in maintaining the company's global competitiveness.

Another obstacle faced by small businesses is that innovation is one of the basic instruments of a new growth strategy to enter the market, to increase existing market share and provide the company to be competitive. (Günday et al., 2011). One way to develop and improve competitive advantage and improve performance is through the utilization of resources and improving innovation for small businesses (Hilmi and Ramayah, 2008). SMEs who are able to innovate will enable it to survive in competition and gain significant benefits. A review of the management literature on innovation relationships with company performance shows inconsistent results. A number of researchers found innovation to have a positive relationship with company performance (Garcia \& Calantone, 2002), but others found a negative relationship between the two (Jermias \& Armitage, 2000). Lin and Chen (2007) show that innovation is an important factor to maintain the company's global competitiveness. Innovation as a driver of corporate growth, driving future success and driving the company to survive in the global economy. 


\section{Conclusion}

Innovation is the answer to the dynamic conditions of a rapidly changing business environment. The innovation capability of a company will ensure the company's competitive ability. Therefore innovation is an important concept to be studied because innovation also gives a big impact to the success of the company. In the opinion of Cooper \& Emory (1995), innovation plays an important role in the organization because innovation creates and sustains sustainable competitive advantage. Creativity and innovation by definition involve the creation of something new that is the center of the entrepreneurial process (Barringer and Ireland, 2006). Creativity and innovation are considered inseparable from entrepreneurship, which in turn is embodied in the act of starting and running a company (Baldacchino, 2009), creativity is not enough to just come up with ideas.

\section{References}

Agarwal, S., S.N. Ramaswami. 2003. The effective organizational commitment of salespeople: An expanded model. Journal of Personal Selling and Sales Management, Vol. XIII, No. 2.

Amos, Neolaka. 2007. Kesadaran Lingkungan. Jakarta: Rieneka Cipta.

Ardiana, I.D.K.R. 2010. Kompetensi SDM UKM dan Pengaruhnya Terhadap Kinerja UKM di Surabaya. Jurnal Manajemen dan Kewirausahawan, Vol. 12. No. 1.

Awang. A Khalid. A.S, Yusuf. A Kassim. M. K, Ismail. M, Zein. R. S, and Madar. S. 2009. "Entrepreneur Orientation \& Performance Relation of Malaysian Bumiputera SMEs: The Impact of Some Perceived Environment Factors. International Journal of Business and Management ISSN 1833-3850.

Baldacchino, C. 2009. Entrepreneurial Creativity and Innovation. The First International Conference on Strategic Innovation and Future Creation. University of Malta, Malta.

Bambang Prasetyo. 2006. Metode Penelitian Kuantitatif: Teori dan Aplikasi. Raja Grafindo Persada : Jakarta.

Barringer, Bruce R., and R. Duane Ireland. 2006. Entrepreneurship "Successfully Launching New Ventures.” Pearson Education, Inc., Upper Saddle River, Prentice Hall, New Jersey, United States of America.

Baum, J. R., Locke, E. A., \& Smith, K. G. 2001. A multidimensional model of venture growth. Academy of Management Journal, 44, 292-303.

Beal, Reginald M. 2000. Competing Effectively: Environmental Scanning, Competitive Strategy, and Organizational Performance in Small Manufacturing Firm. Journal Of Small Business Management.

Brock, W.and Evans, D. 1986. The Economics of Small Business: Their Roles and Regulations in US Economy, Holmes \& Meier Publishers, Teaneck, NJ.

Cannon, M.D. \& Edmondson A.C. 2001. Confronting failure: Antecedents and consequences of shared beliefs about failure in organizational work groups. Journal of Organizational Behavior, 22 (2), 161-177.

Chow, I.H. 2006. The Relationship between Entrepreneurial Orientation and Firm Performance in China. S A.M. Advanced Management Journal, 71 (3), 11-20.

Cole, L.E., \& Cole, M.S. (2005). Employee satisfaction and organizational performance: A summary of key findings from applied psychology.

Cooper, Donald R. dan C. William Emory. 1995. Metode Penelitian Bisnis, Edisi 5,. Jilid 1. Terjemahan Ellen G. Sitompul. Erlangga.

Covin, J. G., \& Slevin, D. P. 1989. Strategic management of small firms in hostile and benign environments. Strategic Management Journal, 10, 75-87. 
Covin, J. G., Green, K. M., dan Slevin, D. P. (2006). Strategic process effects on the entrepreneurial orientation - sales growth rate relationships. Entrepreneurship Theory and Practice, 30(1): 57-81.

Covin, J.G and T. Covin. 1990. Competitive Aggressiveness Environmental Context, and Small Firm Performance. Entrepreneurship Theory and Practice. 14 (4). Pp.35- 50.

Daft, Richard L. 2005. Management, 6th Edition. South of Western Thomson Learning, Singapore.

Demirbag, M., Tatoglu, E., Tekinkus, M. and Zaim, S., 2006, “An analysis of the relationship between TQM implementation and organizational performance: evidence from Turkish SMEs", Journal of Manufacturing Technology Management, Vol. 17 No. 6, pp. 829-47.

Dess, G., G. Lumpkin, and J. Covin. 1997. Entrepreneurial strategy making and firm performance: Test of Contingency and Configurational Models. Strategic Management Journal, 18 (1), 2-23.

Dhewanto, Wawan, dkk. 2015. Manajemen Inovasi untuk Usaha Kecil \& Mikro. Bandung: Alfabeta.

Drucker, P. F. 1993. Postcapitalist Society. New York: HarperCollins Publishers.

Ferreria, J., \& Azevedo, S.G. 2008. Entrepreneurial orientation and growth of firms: Key lessons for managers and business professionals. Problems and Perspectives in Management, 6(1), 82-88.

Garcia, R. \& Calantone, R. 2002. A critical look at technological innovation typology and innovativeness terminology: a literature review. Journal of Product Innovation Management, 19 (2), 110-132.

Gibson Jr, G.E., Wang, Y.R., Cho, C.S., \& Pappas, M.P. 2006. What Is Preproject Planning, Anyway? Journal of management in engineering, 22(1), pp. 35-42.

Gray, Clive, dkk. 2002. Pengantar Evaluasi Proyek. Jakarta: PT. Gramedia Pustaka Utama.

Günday, G., Ulusoy, G., Kılıç, K., \& Alpkan, L. (2011). Effects of innovation types on firm performance. Int. J.ProductionEconomics, 133(2011), 662-676.

Hafeez, Samraz \& Muhammad, Bakhtiar. 2012. The Impact of Service Quality, Customer Satisfaction and Loyalty Programs on Customer's Loyalty: Evidence from Banking Sector of Pakistan, Vol.3, No.16, 200-209.

Hart, S.L. 1992. An integrative framework for the strategy-making process. Academy of Management Review, 17, 327-351.

Hassim, AA, Nizm. A Talib. A, Abu Bakar. A.R. 2011. The Effects of Entrepreneurial Orientation on Firm Organisational Innovation and Market Orientation Towards Firm Business Performance. International Proceedings of Economics Development \& Research, Vol. 10.

Hasibuan, H. Malayu. 2006. Manajemen Sumber Daya Manusia Ed. Revisi. Jakarta: Bumi Aksara.

Hilmi, M. F., \& Ramayah, T. 2008. Market Innovativeness of Malaysian SMEs : Preliminary Results from a First Wave Data Collection. Asian Social Science, 4(12), 42-49.

Hitt, M. A., Ireland, R. D., \& Hoskisson, R. E. 1999. Strategic management: Competitiveness and globalization: concepts and cases. Cincinnati, Ohio: South-Western College Pub.

Hunter, Rodgers, R., J. E., \& Rogers, D. L. 1993. Influence of top management commitment on management program success. Journal of Applied Psychology, 78(1), 151-155.

Hurley, R.F., Hult, G.T.M., and Knight, G.A. 2003. Innovativeness: its antecedents and impact on business performance. Industrial Marketing Management, Vol. 33, pp. 42938.

Idrus, M.S. 1990. Peranan Usaha Kecil di Indonesia dan Prospeknya. Lintasan Ekonomi.Malang: Nusantara Print. 
Kisengi S, Olweny T. 2014. Influence of education on entrepreneurial behavior among small and medium enterprise owners in Nairobi CBD, Kenya. Jurnal Science Research 3(11): 1481-1483.

Komariah. 2012. Hubungan Pengetahuan, Motivasi, dan Supervisi dengan Kinerja Pencegahan Infeksi Nosocomial di RSUD Haji. Jurnal Kesmas

Krauss, S. E. 2005. Research Paradigms and Meaning Making: A Primer. The Qualitative Report, 10(4), 758-770.

Kuswantoro, A. 2012. Penanaman nilai-nilai pendidikan kewirausahaan berbasis unit produksi di SMKN 6 Semarang. Eco-Entrepreneurship Seminar \& Call Paper "Improving Performance by Improving Environment.

Lee, J. and Miller, D. (1996). Strategy Environment and performance in Two Technological Contex: Contingency Theory in Korea. Organization Studies. Vol. 17. No. 1. pp.729750.

Lee, D Y. and Tsang E W K. 2001. The Effect of Entrepreneurial Personality, Background and Network Activities on Venture Growth. Journal of Management Studies 38-4 pp 583- 602.

Lin, Carol Yeh-Yun., and Mavis Yi-Ching Chen. 2007. Does innovation lead to performance? An empirical study of SMEs in Taiwan. Management Research News, Vol. 30 Issue: 2, pp.115-132.

Lumpkin, G. T. \& Dess, G. G. 1996. Clarifying the entrepreneurial orientation construct and linking it to performance. Academy of Management Review, 21 (1): 135-172.

Miller, Danny., and Peter H. Friesen. 1984. A Longitudinal Study of the Corporate Life Cycle. Management Science, 1984, vol. 30, issue 10, pages 1161-1183.

Miles, R. E., and Snow, C. C. 1978. Organizational Strategy, Structure, and Process. New York: Mc Graw.

Miles, G., Miles, R.E., Perrone, V., and Edvinsson, L. 1998. Some conceptual and research barriers to the utilization of knowledge. California Management Review, 40(3), 281 288.

Mintzberg, H. 1973. The nature of managerial work. New York, Harper Collins.

Mintzberg, H. 1992. The Structuring of Organizations. Prentice Hall. New York.

Pattimukay, Hengky V.R. 2008. Membangun Jiwa Entrepreneurship dalam Organisasi (Suatu Proses Kepemimpinan Organisasi.

Proctor, Brigid. 2000. Group Supervision, a guide to creative practice. Great Britain by bidders Ltd. California.

Segev, E. 1987. Strategy, strategy-making, and performance in a business game. Strategic Management Journal, Vol. 8:6, p. 565-577.

Scarborough, N.M. \& Zimmerer T.W. 1993. 4th ed. Effective Small Business Management. New York: Macmillan.

Snow, C.C., \& Hambrick, D.C. 1980. Measuring organizational strategies: some theoretical and methodological problems. Academy of Management Review, 5: 527-538.

Tambunan, Tulus T.H. 2003. Perkembangan Sektor Pertanian di Indonesia, Beberapa Isu Penting. Jakarta: Ghalia Indonesia

Tambunan, T. 2012. Pasar Bebas ASEAN, Tantangan, Peluang dan Ancaman bagi UMKM Indonesia, Infokop.

Wiklund, J. 1999. The Sustainability of The Entrepreneurial Orientation-Performance Relationship. Entrepreneurship Theory and Practice. 24(1): 37-47.

Yang, Chung-Wen (2006), dengan judul The Effect of Leadership and Entrepreneurial Orientation of Small and Medium Enterprises on Business Performance in Taiwan. Dissertation. The university of the Incarnate Word. 
Zhou, Kevin Zheng, Chi Kin (Bennett) Yim, and David K. Tse. 2005. The Effects of Strategic Orientations on Technology- and Market-Based Breakthrough Innovations. Journal of Marketing, Vol. 69, No. 2, pp. 42-60. 